International Journal of Social Science (IJSS)

Vol. Issue.5 February 2022, pp: 643-656

ISSN: 2798-3463 (Printed) | 2798-4079 (Online)

DOI: https://doi.org/10.53625/ijss.v1i5.1307

\title{
IMITATING THE EMANCIPATION OF HINDU FEMALE CHARACTERS IN BALINESE WAYANG LEGENDS
}

\author{
By \\ Gede Yoga Kharisma Pradana ${ }^{1}$, Ni Made Ruastiti ${ }^{2}$ \\ ${ }^{1}$ Department of Hotel Management (DIV), Tourism Institute and International Business, Indonesia \\ ${ }^{2}$ Department of Dance, Faculty of Arts, Indonesia Institute of the Arts Denpasar, Indonesia \\ Email: ${ }^{1}$ yoga@ipb-intl.ac.id ${ }^{1}$
}

\begin{tabular}{l}
\hline \hline Article Info \\
\hline Article history: \\
Received Nov 16, 2021 \\
Revised Dec 26, 2021 \\
Accepted Jan 25, 2022 \\
\\
\hline Keywords: \\
Emancipation, Hindu woman, \\
Legend, Wayang performance
\end{tabular}

Corresponding Author:

Gede Yoga Kharisma Pradana,

Department of Hotel Management (DIV),

Tourism Institute and International Business,

Kecak Dance Street 12, Denpasar, Bali, Indonesia.

Email: yoga@ipb-intl.ac.id

\begin{abstract}
The purpose of this study was to analyze the role of Hindu women based on the legends of the wayang performance. Many post-colonial Balinese Hindu women began to leave their culture. To be more empowered, they do not have to leave their culture. They are still relevant as role models, like Dewi Anjani, Srikandi, and Dewi Kunti's struggle in the legends. The issues are as follows: (1) What is the image of Dewi Anjani, Srikandi, and Dewi Kunti's struggle? What can be learned from the three Hindu female figures in the legends? All the data was collected through documentation, observation, and interviews with informants in Denpasar. Qualitative-interpretative descriptive analysis is supported by applying symbol, hegemony, and deconstruction theory. The results show that Dewi Anjani is a female character who is able to fight for her rights equal to her two brothers. Srikandi is a female character who is able to fight on par with the leader of the knights on the battlefield. Meanwhile, Dewi Kunti was able to show a firm attitude during the Pandawa conflict. The images of the three figures are role models for the reconstruction of post-colonial Balinese Hindu women in responding to the challenges of globalization.
\end{abstract}

This is an open access article under the CC BY-SA license.

\section{INTRODUCTION}

According to Gramsci in Simon [1], hegemony affects women's behavior in making all men's decisions. In the political, socio-cultural, and economic context, the position of Indonesian women still tends to be weaker than that of men. When men are in power, women do what men decide without any resistance. The phenomenon of hegemony that reflects the weak position of women against men occurs in post-colonial Balinese Hindu women as workers in the tourism sector. These include the absence of Balinese Hindu women in company leadership positions, their minimal role as union administrators in the tourism sector, and the amount of discriminatory treatment they receive. Supposedly, the rights of men and women in occupying leadership positions such as being hotel managers in the tourism sector can be realized. Despite having a bachelor's degree, Balinese Hindu women are still very rare to become leaders in the tourism sector, such as hotel managers. The majority of them are just ordinary staff, and only a small percentage of them can become hotel managers in the tourism sector. According to Karmini [2], only 1 person out of 169 Balinese Hindu women who work in five-star hotels becomes a hotel manager.

The hegemony of men over women is also seen in the tourism trade union organization in Badung district. The role of post-colonial Balinese Hindu women in tourism trade union activities is very passive and very few of them are interested in becoming tourism workers' union administrators in Badung district. The very passive role of Balinese Hindu women in tourism trade union activities has an impact on the lack of social movements that fight for their rights in their careers [3]. The implication is that the demands of Balinese Hindu women workers are often not 
met amidst the enforcement of service quality standards for hotels and other companies in the tourism sector. In industrial relations, Pancasila and dynamic cooperation between the workers and the management and owners must be upheld [4].

Enforcement of harmonious relations between owners, administrators, and workers should be able to solve social problems in businesses in the tourism sector. All social problems that violate the principle of gender equality must be reduced. All forms of discriminatory treatment against women need to be responded to with constructive solutions. Empowerment efforts are needed among women in the midst of discriminatory treatment. Thus, efforts to empower post-colonial Balinese Hindu women to improve the quality of family, community, and national welfare need to be continuously fought for. In fact, the practice of empowering women became an important recommendation at the 1994 International Congress on Population and Development (ICPD) in Cairo. The orientation of this empowerment practice is not only to make women equal to men, but also to improve their quality, capacity, independence, and internal strength to fight for their rights in making life choices. Empowerment strategies require a participatory role in improving the quality and capacity of internal strengths in the midst of dynamic conditions $[5,6,7]$.

In the midst of globalization, the struggle of women to realize gender justice is dynamic, going up and down. Gender justice related to equality actually requires efforts to foster the role of women as equal partners with men to increase their active role in development activities, including efforts to create healthy, prosperous, and happy families. Furthermore, efforts to increase women's living standards that are equal in gender construction by 2030 are also listed in the Millennium Development Goals/MDGs and Sustainable Development Goals/SDGs since the end of 2015. The Sustainable Development Goals (SDGs) program on gender equality emphasizes increasing the use of information technology and communication for women's empowerment [8]. In addition, the sustainability of a conducive environment for health and the economy also affects the achievement of the education quality target.

Some Balinese Hindu women have actually obtained gender justice and equality in access to education, as experienced by generation I Goesti Ajoe Amba in the 1930s, a Hindu female figure in North Bali during the Dutch colonial period. She is known as a Balinese Hindu female figure who is empowered, diligent, responsible for her family and able to maintain the cultural traditions of her community. She is a model for an ancient Balinese Hindu woman who is able to maintain cultural traditions even though she is known to be educated in her association with modern life, can drive a car, play tennis, usually wears modern clothes and can speak Dutch. Although she became a figure in the public sector in modern life, this educated woman during the Dutch colonial period was also considered a figure who was able to carry out the Balinese Hindu tradition [9].

The emancipation of women in achieving equality with men is also reflected in the legend of Balinese Wayang, such as the role of Dewi Anjani in the Ramayana epic, Srikandi and Dewi Kunti in the Mahabharata epic. The story of wayang performances serves as a guide for life, education, and life rules, as well as a spectacle of entertainment $[10,11]$.The sustainability of wayang cannot be separated from the manifestation of noble culture and ancestral heritage that contain educational values $[12,13]$. The emancipation of Hindu women in the wayang performing arts is not only about equalizing themselves with men, but also the act of fulfilling tasks in the domestic sphere and in the form of loyalty and sacrifice as life partners for their husband. As Pradana [14] said, the story of wayang performing arts contains the teachings of justice through the example of carrying out duties, sacrifice, and loyalty. Through the legend of wayang performances, post-colonial Balinese Hindu women should also be able to become empowered figures because they actually have the opportunity to an equal degree with men to study in the formal education sectors for their success in life.

The Ramayana and Mahabrata epics in wayang shows show the ideal form of women's emancipation socially, both in contributing to the public and domestic spheres, so that they deserve to be used as role models in reconstructing women's understanding of the meaning of emancipation and freedom. Wayang arts can have social, cultural, and economic ramifications in the public sphere [15]. The relationship between social networks, cultural understanding, and economic opportunities can not be separated from the quality of wayang performances [16]. On the other hand, the fulfillment of obligations between the domestic sphere and the opportunity to become public figures must be supported by the community through the formation of gender-responsive agency policies [17].

Since the declaration of independence of the Republic of Indonesia, Balinese Hindu women have continued to strive for gender justice in the domestic sector as well as in the public sector. Equality in the public sphere is manifested in professional development in various fields of work and the role of women in social life [18]. Many Balinese Hindu women have struggled to become successful politicians, working as Indonesian National Army, police, managers, assistants, and professional technicians as well as traders (see Table 1). 
International Journal of Social Science (IJSS)

Vol. Issue.5 February 2022, pp: 643-656

ISSN: 2798-3463 (Printed) | 2798-4079 (Online)

DOI: https://doi.org/10.53625/ijss.v1i5.1307

Table 1

Bali Population by Type of Work in 2017

\begin{tabular}{|c|l|r|r|r|}
\hline No & \multicolumn{1}{|c|}{ Type of work } & Male & \multicolumn{1}{c|}{ Female } & \multicolumn{1}{c|}{ Total } \\
\hline 1 & Indonesian National Army/Police & 12,673 & 627 & 13,300 \\
\hline 2 & Manager & 35,798 & 12,252 & 48,050 \\
\hline 3 & Entrepreneur & 57,804 & 64,512 & 122,316 \\
\hline 4 & Professional technicians and assistants & 66,129 & 24,710 & 90,839 \\
\hline 5 & Administration staff & 99,933 & 83,857 & 183,790 \\
\hline 6 & Service and sales personnel & 304,370 & 383,468 & 687,838 \\
\hline 7 & Agricultural, forestry and fishery workers & 230,444 & 166,512 & 396,956 \\
\hline 8 & Craft worker & 225,799 & 203,584 & 429,383 \\
\hline 9 & Machine operators and assemblers & 79,638 & 4,130 & 83,768 \\
\hline 10 & Freelance & 203,199 & 138,948 & 342,067 \\
\hline & Total & $1,315,787$ & $1,082,600$ & $2,398,307$ \\
\hline
\end{tabular}

(Source: Bali in Numbers, 2018)

As shown in table 1, the emancipation of post-colonial Balinese Hindu women in fighting for their existence has been proven by their involvement in carrying out public roles in service and business affairs which are increasingly developing in globalization. This phenomenon of globalization has also increased the opportunity for fast access to information and entertainment for various groups in various parts of the world. These symptoms are characterized by the many sources of information available through social media channels such as Facebook, YouTube, and Instagram. As Pradana [19] confirms, a variety of information can be obtained through electronic media.

Women are expected to play an active role in taking an active part in the development of media and information technology for economic development. The presence of the sophistication of media and information technology should be useful and well managed by women to be more empowered, considering that it has become a promising prospect for the position and role of women to be more empowered in responding to the challenges of globalization as part of the development of world civilization [20].

In facing the challenges of globalization, the role of Balinese Hindu women needs to be reconstructed again by imitating the emancipation of women in the Ramayana epic (Dewi Anjani) and Mahabarata epic (Srikandi and Dewi Kunti). This scientific work aims to discuss the reconstruction of the role of Balinese Hindu women by referring to the representation of the emancipation of three Hindu female figures in the art of wayang performances: Dewi Anjani, Srikandi, and Dewi Kunti. For this reason, the problems discussed in this scientific paper are: (1) What is the image of the emancipation of the struggle of Dewi Anjani, Srikandi, and Dewi Kunti as Hindu female figures in the legend of Balinese Wayang performances? (2) How can post-colonial Balinese Hindu women follow in the footsteps of Dewi Anjani, Srikandi, and Dewi Kunti as Hindu female figures in Balinese Wayang legend?

This paper is the result of research conducted using qualitative methods in the perspective of cultural studies. Document studies, observation of wayang performances, and interviews with eight informants from the elements of puppet arts: actors, people who love wayang art, and observers of Balinese Wayang performing arts in Denpasar were used to collect data. Qualitative and interpretive analysis were carried out by applying symbol theory, hegemony theory, and feminist theory. It is hoped that the discourse that reveals the image of the emancipation of the figures of Dewi Anjani, Srikandi, and Dewi Kunti is not only limited to cultural knowledge that contributes to cultural studies scholarship, but also becomes a source of emancipation in the tradition of shadow puppet performance, which can inspire post-colonial Balinese Hindu women to develop their potential to be more empowered in the midst of the demands of globalization.

\section{RESEARCH METHOD}

This article on imitating women's emancipation in the legends of Balinese Wayang performances was completed using a qualitative method. Qualitative methods are known to be effective in finding and analyzing qualitative data [21]. All primary data was collected in Denpasar through observations of Balinese Wayang performances, and interviews with actors, lovers, and observers of Balinese Wayang as informants. All this data is complemented by secondary data that has been collected through a document study of literacy about the legends of Wayang performances. Symbol theory, hegemony theory, and deconstruction theory were used to analyze and interpret all data qualitatively and interpretively. 


\section{RESULTS AND ANALYSIS}

\subsection{The Emancipation Image of Dewi Anjani, Srikandi and Dewi Kunti}

According to the theory of symbols, an icon, sign, or certain movement contains its own meaning [22]. Every form, play, character, and whatever else is in the art of wayang performances contains cultural intentions and values that can be developed as guidelines. A puppet show has a specific purpose or message. First, about the universe. In general, the puppeteer community of the archipelago classifies the world of wayang into three levels, namely the mythological level, the ritual level, and the epic level. The mythological level is the highest level in the art of wayang and is related to the gods and is the center of holiness and magic. The epic level is the lower level, the arena level of the hero characters. The ritual level is the intermediate level, the level that tries to bring together the mythological and epic levels in a ceremony. To bring together the epic level with the mythological level, certain processes must be carried out according to the epic-ritual-mythological path. Second, social strata generally classify relations into two categories, namely old, young and rank. The basic rule in determining strata, both social strata within an epic and epic characters with myths, is determined by the position of each character in the art of Balinese Wayang [23]. The image of the emancipation of the puppet characters can be found through the actions, the character, and the status (social strata) of the puppet character concerned. In the following, we discuss the image of the emancipation of three Hindu female figures in the legends of the Balinese Wayang performance, namely Dewi Anjani in the Ramayana epic, Srikandi, and Dewi Kunti in the Mahabharata epic.

\subsubsection{The Image of Dewi Anjani's Emancipation}

Dewi Anjani is a protagonist in the Ramayana epic. She is known as a Hindu woman with an egalitarian mentality, who is patient and tough as a single parent and feels she has equal rights with her two younger brothers, namely Arya Bang and Arya Kuning. In the Ramayana epic, Dewi Anjani is the eldest child of Rsi Gotama and Dewi Indradi. Dewi Anjani has a beautiful face, but because of her mistake, she turns into a monkey, has a son with white hair, and is forbidden to go back to studying at the pasraman until she can return to normal as an ordinary human with sense of humanities.

Dewi Anjani has a Cupu Manik Astagina. When opened in it, you can see all the events that occur on earth and in the heavens up to the seventh level. Cupu Manik Astagina is a gift from Dewa Surya to Dewi Indradi. Dewi Indradi gave Cupu Manik Astagina as a gift to Dewi Anjani after wanting to study Hinduism with her brother at the pasraman. Even though, it is a woman who will take care of the domestic sector, Dewi Anjani is treated equally by her parents in the Hindu religious education process.

One day, his two younger siblings came when Dewi Anjani was using her heirloom, named Cири Manik Astagina. They were very entertained by the magic of the heirloom. His two younger siblings then demanded the same inheritance from Rsi Gotama. Rsi Gotama summoned Dewi Anjani to explain the origin of Cupu Manik Astagina. Dewi Anjani said that the heirloom was a gift from her mother, Dewi Indradi. When Rsi Gotama sought confirmation of the truth of Dewi Anjani's confession, Dewi Indradi did not respond. To resolve family conflicts related to inheritance, the heirloom named Cupu Manik Astagina was thrown away by Rsi Gotama into the forest. 
International Journal of Social Science (IJSS)

Vol. Issue.5 February 2022, pp: 643-656

ISSN: 2798-3463 (Printed) | 2798-4079 (Online)

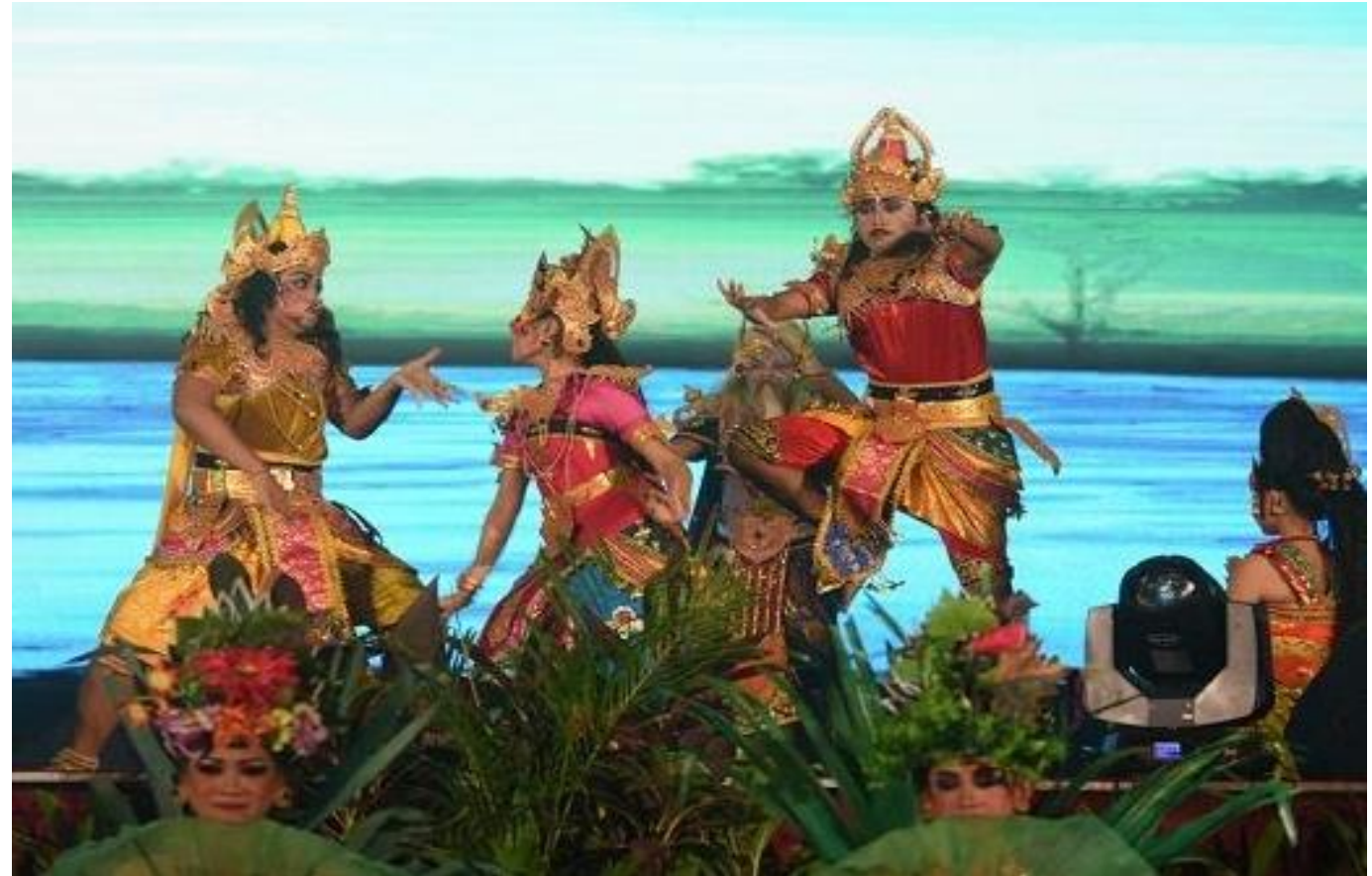

Figure 1. The scene of Rsi Gotama and Dewi Anjani's conflict with her two younger brothers in an Innovative Balinese Wayang Wong show

(Source: Ruastiti, 2019).

Dewi Anjani, Arya Bang and Arya Kuning decided to look for Cupu Manik Astagina in the middle of the forest without Rsi Gotama's permission. They were united in looking for Cupu Manik Astagina at a Sumala lake in the middle of a forest near the pasraman. The conflict between Dewi Anjani, Arya Bang, and Arya Kuning arose after Arya Bang and Arya Kuning came out of the Sumala lake and turned into Subali and Sugriwa. The manifest conflict between Subali and Sugriwa is unavoidable after they do not find Cupu Manik Astagina and forget that they are both brothers. On the one hand, Dewi Anjani turned into a monkey after washing her face in Sumala lake.

The manifest conflict between Subali and Sugriwa could be stopped by Rsi Gotama after Dewi Anjani reported the conflict over Cupu Manik Astagina in the middle of the forest to the pasraman administrator. Subali, Sugriwa, and Dewi Anjani were about to repent and return to being pasraman students, but it seemed it was too late. Subali, Sugriwa, and Dewi Anjani's request to return to being ordinary people through ritual mediation led by Rsi Gotama did not get a positive response from the gods. Rsi Gotama looked desperate and then gave the same opportunity to Subali, Sugriwa, and Dewi Anjani to directly appeal to the gods through the practice of brata and fasting. It is said that during their fasting practice, Dewi Anjani was punished by Dewa Bayu for drinking the forbidden lake water. As a result, Dewi Anjani had to give birth to a son in the form of a white-haired monkey and raise him to adulthood. After Dewi Anjani's success in educating her own son to become a magic knight and servant of the king of Ayodya Pura, known as Hanoman, Dewi Anjani's request to become a human was finally granted by the gods. According to Sudibyoprono [24], Dewi Anjani, who is like a monkey, can eventually become a beautiful woman like a nymph after receiving the forgiveness of the gods and giving her the possibility to return to being a student at pasraman. In the midst of the lack of assistance, limited guidance, and Dewi Anjani's lack of understanding of Hinduism, Dewi Anjani's persistence as a Hindu female figure to achieve her desires did not seem to disappoint the emancipation of Rsi Gotama as her teacher at the pasraman and Hindu figures to practice fasting and brata, which is equivalent to the fasting and bratha practices of her brothers.

\subsubsection{Srikandi's Emancipation Image}

Srikandi is a masculine character in the Mahabrata epic. This protagonist plays a public role as a member of the war soldiers who sided with the Pandawa. Srikandi is a Hindu woman who is brave, has a loud voice, is tough and capable of archery, has self-confidence and a great spirit to fight [25]. Like a man, he dared to fight head to head on the battlefield against Bisma. Bisma is a character who sided with the Kurawa in the Mahabharata epic, an antagonist who has supernatural powers in the optional form of choosing the time of his death [26]. Therefore, Bisma 
should not be killed by anyone when the act is against his will to die. However, after realizing that Srikandi is the reincarnation of Amba, a woman who is desperate to die because of Bisma, a woman he once loved but didn't marry because of his oath as a mighty knight, Bisma chooses to relent when fighting Srikandi. Bisma immediately threw away all his war weapons on the battlefield of Bharata Yuda after Srikandi's arrows managed to pierce his heart. At that time, Bisma had lost. After that, he never retaliated or evaded any Srikandi attacks, along with the troops who sided with the Pandawa. Bisma finally died on the battlefield after the Kurawa and Pandawa listened to his last message and found it a lucky day to die. Thus, Srikandi finally died as a warrior who lost to Aswatama on the battlefield of Bharata Yuda.

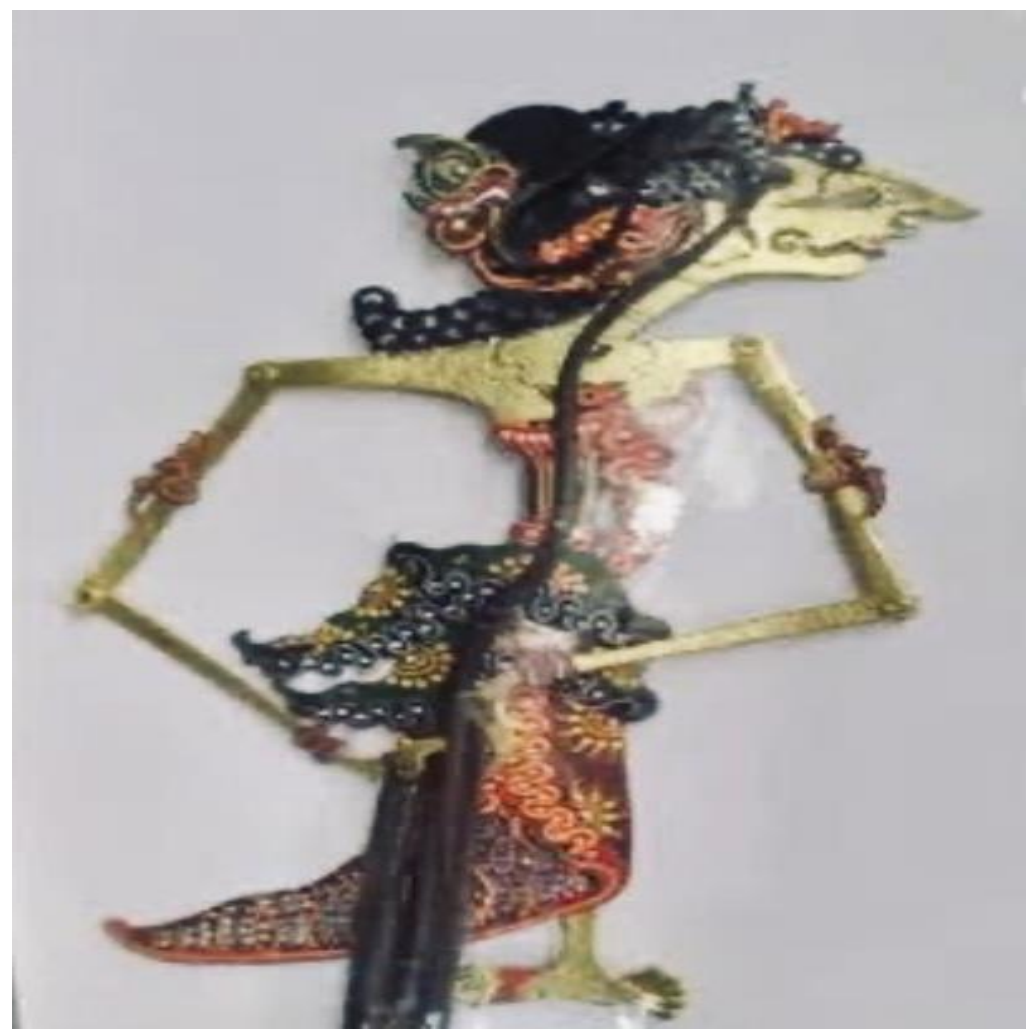

Figure 2. The Srikandi Figure in the Traditional Balinese Shadow Puppet Performance (Source: Pradana, 2022).

\subsubsection{Dewi Kunti's Emancipation Image}

In the Mahabharata epic, Dewi Kunti is the ideal mother figure. This protagonist is a wise Hindu woman who is able to transcend family controversies in raising children and has a high degree of dedication to educating the Pandawa to become a superior generation [27]. This can be seen from how Dewi Kunti is able to nurture and raise the Pandawa characters in the Mahabharata epic.

Dewi Kunti is the first educator of the Pandawa as well as the second guide to guide her five sons in dealing with the school environment and the wider social environment. This shows that parents play a role in laying the first foundation for children in the formation of personality. Thus, social relations in the family become important, especially the relationship between mother and child. In the period of growth until the war of Bharata Yuda, Dewi Kunti always guarded and followed the mental development of the Pandawa. Dewi Kunti always communicates with the Pandawa whenever they are faced with a problem in a new situation that they do not understand. At that moment, Dewi Kunti plays an important role in transmitting cultural values that can contribute to the patience, politeness, loyality, fanatic and unyielding attitude of the Pandawa in dealing with every problem they face.

Ethnic abstractions and organizational practice orientations in understanding norms, obeying rules, acting, working, and maintaining or building image characteristics are examples of cultural values $[28,29,30,31,32,33$, $34,35,36,37]$. According to Geertz [38], there are cultural values that exist in society that are applied in building 
International Journal of Social Science (IJSS)

Vol. Issue.5 February 2022, pp: 643-656

ISSN: 2798-3463 (Printed) | 2798-4079 (Online)

Crossref DOI: https://doi.org/10.53625/ijss.v1i5.1307

attitudes and communication between mothers and children. These cultural values include being alert, shy, bighearted and responsible. The alert attitude encourages children to be able to avoid all forms of manifestations of their fear or to save themselves from the impact of their bad actions. Meanwhile, shyness has the potential to build an image of not being greedy, formed from sufficient internalization of children to appropriate standards and shame when acting inappropriately. In contrast to the attitude of reluctance awakened by the manifestation of respect for others, which has the potential to bring up new sympathy from people who do not yet know Thus, a big-spirited attitude can arouse admiration from others who want to have integrity and uphold justice. The responsible attitude encourages children to be aware of their obligations based on the status they already have.

In the lives of the Balinese Hindu society, Dewi Kunti is an example of a manifestation of a Balinese Hindu woman who is patient and tough in acting as a single parent for the great life of Pandawa in Mahabrata epic. The mother figure is present in mentally preparing her children for their social environment. As stated by Giddens [39], the role of mothers is very important in socializing and enculturating cultural values into children as the next generation.

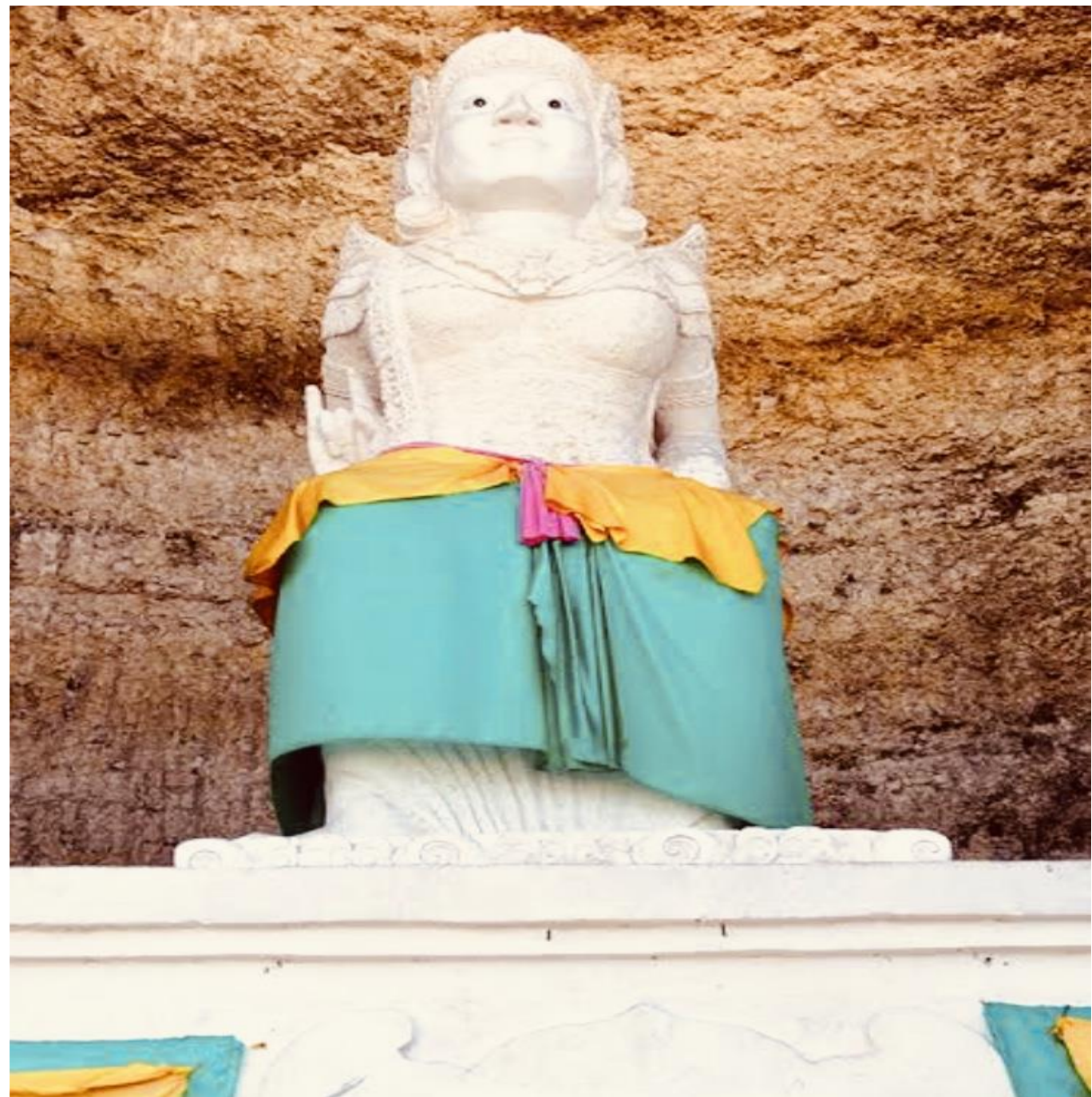

Figure 3. The figure of Dewi Kunti as a Balinese Wayang Statue on Pandawa Beach, Bali.

(Source: Yoga, 2022).

\subsection{Reconstruction of the Role of Post-colonial Balinese Hindu Women in the Midst of Globalization Challenges}


The flow of globalization is influenced by the industrial revolution. The industrial revolution is a type of rapid progress process that has been very beneficial to modernization. The industrial revolution has actually been around since the mid-19th century and has developed into four stages of progress in human civilization. The development of the industrial revolution phase in world civilization has given an articulative difference in terms of its usefulness. The first phase (1.0) results in the invention of the machine, which focuses on production mechanization. The second phase (2.0) has progressed to the mass production phase, which includes quality control and standardization. The third phase (3.0) begins the mass uniformity stage, which is based on computerized integration. The fourth phase (4.0) brought with it digitalization and automation of internet integration with manufacturing [40]. Cyber technology, artificial intelligence, and the Internet of Things (IoT) were also developed during this phase. Companies can make quick and correct decisions using IoT and big data [41].

The industrial revolution 4.0 has contributed greatly to the acceleration of modernization in various parts of the world. Thus, the opportunity to become a socialite even among Jet- $\mathrm{Z}$ is greater than in previous times. Socialites are known as modern women who have the potential to be independent and able to express themselves like public figures in the city. They have the potential to be successful in collaborating and building social networks in international relations. The Jet- $Z$ are known as socialites in big cities who can be classified as not poor, the most shopaholic and materialistic. The Jet- $Z$ are also seen as having the most potential for free expression after their success in building social networks and going international. This gave rise to a single stigma that to be empowered, one had to be established by first becoming a modern woman, then becoming a Jet-Z group member, and then going international. However, some of these opportunities only become mirages or disasters, which adds to the dilemma among post-colonial Balinese Hindu women who are experiencing a capital crisis, the magnitude of professional and public demands and the opportunities of globalization. On the one hand, more and more post-colonial Balinese Hindu women imitate popular ways without skill and perseverance, as well as socialite pragmatic ways to become Jet- $Z$ by ignoring Hindu religious teachings and even leaving their traditional culture. On the other hand, this phenomenon is seen as unfair because it has resulted in an increase in the distance between social inequality.

Injustice due to social inequality is a classic problem that has not been resolved until the post-colonial period. The industrial revolution, among others, is also a rapid change. In fact, it has also been instrumental in accelerating the realization of the independence and civilization of various post-colonial nations by being free from the practice of physical colonial oppression. In the midst of the progress of the development of the post-colonial industrial revolution, more and more independent nations in various parts of the world have declared to reject and abolish the practice of physical colonial oppression and agree to support the realization of a peaceful world civilization. The meaning of proficiency in communication, technological sophistication, proficiency in the use of information technology, and the breadth of social connection networks are strengthened in the current of globalization, which is influenced by the progress of the post-colonial industrial revolution. This phenomenon is a valuable globalization opportunity for the advancement of post-colonial women, considering that violence-based penetration and physical force are increasingly losing meaning. In the midst of this great opportunity to be more empowered and more independent in choosing to become a public figure, postcolonial women who are proficient in communication, able to operate advanced technology, proficient in the use of information technology, and have a wide network of social connections are still seen less frequently than men. Not a few of them actually experienced a slump in their efforts to develop themselves into public figures after public demands as well as domestic needs became increasingly difficult to fulfill after holding single parent status. Becoming more modern by becoming a socialite, which should be a solution to being more empowered, independent, and free of expression, is still a necessity for some post-colonial women who are in a slump and have no choice but to rise up in order to improve their fate. The inhibiting factors for women in independent countries in mastering information and communication technologies are education, literacy, language, time, cost, social and cultural norms [8]. Empowerment of social people can also be achieved through quality educational, cultural, and community activities [42].

In the midst of globalization, post-colonial Balinese Hindu women have more opportunities to develop themselves. They are self-sufficient - using digital technology available on their smartphone, they can add insight and listen to various opportunities in various public sectors, such as the economy, politics, and education. They can also increase their capacity for understanding and carrying out their roles as educators and caregivers for their children at home, as exemplified by several Hindu female figures in the legends of Balinese Wayang arts: Dewi Anjani, Srikandi, and Dewi Kunti (See Table 2).

Table 2 
International Journal of Social Science (IJSS)

Vol. Issue.5 February 2022, pp: 643-656

ISSN: 2798-3463 (Printed) | 2798-4079 (Online)

DOI: https://doi.org/10.53625/ijss.v1i5.1307

Images of Hindu Female Figures (Dewi Anjani, Srikandi, and Dewi Kunti) in Balinese Wayang Arts as Role Models for Post-colonial Balinese Hindu Women

\begin{tabular}{|c|c|c|c|}
\hline No & Figure & Character & Role Models \\
\hline 1 & $\begin{array}{l}\text { Dewi Anjani } \\
\text { (Hindu female } \\
\text { character in the } \\
\text { Ramayana epic) }\end{array}$ & $\begin{array}{l}\text { Maintain ethics and morals, she is a protector who is } \\
\text { kind to his two younger siblings, a generation that } \\
\text { adores their parents, collaboration and competition } \\
\text { lessons, desire to learn something (awareness of the } \\
\text { need to learn), it is tough to be a single parent, being } \\
\text { a hermit with the same tenacity as his brother, be a } \\
\text { devoted disciple. }\end{array}$ & $\begin{array}{l}\text { 1) Ethical and moral } \\
\text { attitudes and behavior; } \\
\text { 2) The significance of } \\
\text { technological proficiency; }\end{array}$ \\
\hline 2 & $\begin{array}{l}\text { Srikandi } \\
\text { (Hindu female } \\
\text { character in the } \\
\text { Mahabaratha epic) }\end{array}$ & $\begin{array}{l}\text { Maintain ethics and morals, assertive, passionate, and } \\
\text { self-assured, have a patriotism spirit, be loyal to your } \\
\text { friends, collaboration and competition lessons, dare } \\
\text { to fight openly and frontally against the enemy on the } \\
\text { battlefield, on par with the men who become Kurawa } \\
\text { and Pandawa knights. }\end{array}$ & $\begin{array}{l}\text { 4) Instructions on } \\
\text { collaboration and healthy } \\
\text { competition; }\end{array}$ \\
\hline 3 & $\begin{array}{l}\text { Dewi Kunti } \\
\text { (Hindu female } \\
\text { character in the } \\
\text { Mahabaratha epic). }\end{array}$ & $\begin{array}{l}\text { Wise, self-sufficient single parent, loyal spouse, } \\
\text { collaboration and competition lessons, be equal to } \\
\text { men in public roles when assertive in politics, } \\
\text { protectors and educators who are patient, fair, and } \\
\text { dedicated to their foster children so that the Pandawa } \\
\text { can realize their full potential in the domestic sector. }\end{array}$ & $\begin{array}{l}\text { 5) The need for a strong } \\
\text { mentality to face life's } \\
\text { challenges; } \\
\text { 6) The requirement for } \\
\text { dependability } \\
\text { specifications and } \\
\text { professional-based skills } \\
\text { when performing domestic } \\
\text { and public roles. }\end{array}$ \\
\hline
\end{tabular}

Source: Processed from various sources (Ruastiti, 2019).

Hindu teachings are useful in strengthening character [43, 44, 45]. Reconstruction and strengthening the role of Balinese Hindu women can be done by imitating the characters and images attached to the figures of Dewi Anjani, Srikandi, and Dewi Kunti. First, Dewi Anjani is a girl. Rsi Gotama, who has an attitude and behavior that upholds ethics and morals, In the Innovative Balinese Wayang Wong Performing Arts with the story of Cupu Manik Astagina, Dewi Anjani is told as a Balinese Hindu female figure who is confident and given equal rights with her two younger brothers in studying Hinduism at pasraman. He is also someone who wants to know something, including when he chases and wants to unravel the mystery of Cupu Manik Astagina, who had been thrown out by Rsi Gotama outside the pasraman. Dewi Anjani has the awareness to seek knowledge that is in line with the demands of her time. As in post-colonial, not only Jet $\mathrm{Z}$ but Balinese Hindu women in general have been faced with various globalization opportunities, such as colonial-based anti-violence movements and the empowerment of organizations based on feminism. Opportunities for globalization include the development of economic digitization, the industrial technology revolution, and the diversification of knowledge that can shock humans and change human work processes to be faster and more efficient [20]. In addition, the story of Cupu Manik Astagina also teaches equality between men and women. As a Hindu woman, Dewi Anjani is treated as equal to her two brothers, so Rsi Gotama chose to abolish Cири Manik Astagina instead of having to give it to one of her three favorite students at pasraman. The results of the development of the Ramayana epic, which describes the equal rights of men and women, are highly appreciated in cultural studies. As Rahmat [17] stated, only modern society has a more open view when addressing the division of tasks between men and women. However, it turns out that the legends in Balinese Wayang arts also contains a similar cultural value orientation that, if developed, is still very relevant for post-colonial Balinese Hindu women in their struggle to be more equal and more empowered in the domestic and public sectors.

Second, the Srikandi. In the Mahabarata epic, Srikandi is not just a passive person in the domestic sector, but a firm figure who upholds ethics, morals, enthusiasm, and confidence in the public sector. In the public sector, Srikandi is known as a masculine figure, having successfully played a public role as a member of the Amartha royal 


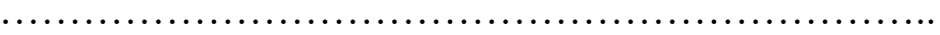

army who sided with the Pandawa in the Bharata Yuda war. In line with the liberal movement based on feminism, which aims to establish a harmonious society based on the principle of equality [46], through the opportunity for emancipation, Srikandi succeeded in obtaining her rights and obligations to carry out public roles as men do, namely to become one of the army generals. She competed with other army generals in a chivalrous manner and managed to defeat the famous general who sided with the Kurawa, the grandfather of the Pandawa and Kurawa, Bisma. He upholds nationalism, defends the kingdom that protects his country, and is loyal to the Pandawa.

The understanding of emancipation as a form of gender-based equality has led modern women to start entering the wider public sphere. Career advancement, increasing social status, obtaining the highest level of education, and attaining the highest positions in the government hierarchy demonstrate a genuine shift from socialites to modern women expressing themselves in the public sector [47]. Similarly, the reactions of the Srikandi figures, Dewi Anjani and Dewi Kunti, reflected the teachings to post-colonial Balinese Hindu women not to give up on self-empowerment, career development efforts, increasing social status, and obtaining a better position in the public sector. This is also consistent with Jet Z's and modern women's responses to freedom and adversity through the struggle for emancipation in globalization. The condition of socialites in responding to the existence of emancipation and freedom in making choices is reinforced by the results of a study by Universal Networks International that found 7 out of 10 modern women are oriented towards achieving success in the public sector [48]. In this regard, the demands for competence from post-colonial Balinese Hindu women have also increased in line with the increasing open access to facilities and infrastructure in the public sector. On the one hand, arrogance and unfair competition in the freedom of competition in the public sector coupled with negative stigma from men are additional challenges for post-colonial Balinese Hindu women that need to be watched out for and addressed to be more empowered through the opportunities of globalization. The condition of the public sector in globalization, which almost unites all groups in various parts of the world, has opened opportunities for all groups without gender discrimination, but there are also those who tend to lead women in the opposite direction from the initial goal of emancipation as a result of being harmed by liberalism [49].

Third, Dewi Kunti succeeded in carrying out her domestic role as Pandu Dewanata's wife. Dewi Kunti is described as a figure who has great patience and loyalty in accompanying the figure of the King named Pandu Dewanata, after Pandu Dewanata married Dewi Madri as his second wife. After Pandu Dewanta died, Dewi Kunti was able to become a successful single parent, nurturing the Pandawa until they became the legend knights. Dewi Kunti's independence is manifested, among other things, in the form of non-formal education about ethics and character, the principles of collaboration and competition for the Pandawa, and accompanying them on live adventures after being expelled from the Astina Pura palace because they lost a gamble with the Kurawa and Sengkuni peacefully.

Dewi Kunti is a Hindu female figure who is strong, mentally tough and successfully carries out her domestic role even though she has to face crisis conditions due to betrayal, loneliness and cheating in her extended family. The magnitude of a mother's position in the domestic sector is strengthened by the argument that the mother's position has a very large influence on the process of internalizing the moral values and personality of her children [50]. The Pandava figures who are able to become great warriors who want to uphold Hindu teachings cannot be separated from the services of Dewi Kunti [51]. Thus, the role of mothers in raising children, educating, and facilitating in the domestic sector is still needed by the community amid the tendency to increase economic status, education, and the active participation of every woman in the productive sector of state development in the flow of globalization [52].

In addition to acting as a mother, Dewi Kunti is able to show her political stance that is firm and equal to men. Dewi Kunti's alignment with the male character is represented in her firmness and courage in taking the oath not to wear the elite palace clothes before Sengkuni's death. This oath was declared after Dewi Kunti felt harassed by Sengkuni at the palace. Dewi Kunti's oath shows resistance in the form of a patriotic attitude. It is a masculine attitude that will not remain silent after receiving discriminatory treatment [17].

Dewi Anjani, Srikandi, and Dewi Kunti are Hindu female figures who are very empowered and deserve to be alternative paths, directions, sources of inspiration, or role models to reconstruct the role of post-colonial Balinese Hindu women who experience problems amid the tendency of every woman to compete to become a socialite in order to be more empowered in addressing the challenges of globalization. The form construction is composed of a model structure, which in total has an image [53, 54]. Reconstruction involves the process of strengthening the image and role model for the structure-form [55]. In general, there are six images of Hindu women's emancipation that can be imitated from the three Hindu female figures in the legends of Balinese Wayang performances, including: 
International Journal of Social Science (IJSS)

Vol. Issue.5 February 2022, pp: 643-656

ISSN: 2798-3463 (Printed) | 2798-4079 (Online)

DOI: https://doi.org/10.53625/ijss.v1i5.1307

1) Dewi Anjani, a Hindu female character in the Ramayana epic, as well as Srikandi and Dewi Kunti in the Mahabharata epic, are examples of ethical attitudes and behavior in family life. This may also be relevant to the demands of globalization, which require every woman to be able to carry out public roles successfully through self-competence, which must be accompanied by good moral behavior.

2) An example of the need for proficiency in the use of technology is reflected in the story of Dewi Anjani and her two sisters, who want to unravel the mystery of Cири Manik Astagina. Post-colonial Balinese Hindu women should want to improve their skills in the use of advanced technology that has developed a lot in the current of globalization, which can be useful for realizing goals more effectively and increasing the meaning of the achievements of the struggle so far.

3) An example of men and women having equal rights. Besides being exemplified by the equality of Dewi Anjani with her two younger brothers, this is also reflected in the character of Srikandi, who, like a man, is able to become a general in the army and dares to fight with enemies on the battlefield.

4) An illustration of the concepts of collaboration and competition. The lives of the three Balinese Hindu female figures illustrate social collaboration and the ability to compete in a healthy manner in carrying out their respective roles, such as the figure of Dewi Anjani, who competes in a healthy manner with her two sisters to find Cири Manik Astagina, the figure of Srikandi, who competes in a healthy manner to become a general of the royal army and is willing to collaborate with the Pandawa, and the competing figure of Dewi Kunti, who is willing to collaborate in a healthy manner with Dewi Madri in nurturing the Pandawa at the palace.

5) An example of the need for mental readiness in facing life's challenges. The three Hindu female figures, Dewi Anjani, Srikandi, and Dewi Kunti, are figures who are empowered and have a strong mentality to face the challenges of life in pre-colonial times. In the midst of various problems in her life, she was able to succeed in educating the Pandawa to become legend knights who highly respected the teachings of Hinduism and led them to become victors in the Bharata Yuda war.

6) Dewi Anjani's single parent status when she cared for Hanoman and Dewi Kunti when she cared for the Pandawa after Dewi Madri and Pandu died. From the story of Dewi Anjani and Dewi Madri, it shows that the status of single parent is actually not a new status known to Hindus in the post-colonial era, the status of absolute failure for Hindu parents in raising their children in the domestic sector, the status of a prohibition for post-colonial Balinese Hindu women to study Hinduism, is not a status that significantly weakens the struggle of post-colonial Balinese Hindu women to be more empowered and become public figures, and is not the main factor behind the failure of post-colonial Balinese Hindu women to compete internationally for globalization opportunities. As precolonial Hindu female figures who bear the status of single parents, they do not give up on carrying the burdens of their lives, are able to show equal roles in the public sector, are able to educate and raise children who are pious in Hinduism, and are able to collaborate and compete in a healthy manner with prominent figures. As for Hindus, they are able to develop the potential of their children to become figures needed in the revitalization of Hindu religious teachings. The example of Dewi Anjani and Dewi Kunti in pre-colonial times is still very relevant for post-colonial Balinese Hindu women, who can be said to have been freed from oppression in physical colonialism as a source of motivation to stay strong when raising children to be pious in Hinduism after their husbands died, not to despair before they were born. They are able to find a replacement for a new life partner in raising children so that they are able to be pious in Hinduism. They do not give up on raising children even though their husbands leave them because of divorce. They are strong in carrying out domestic roles as well as roles in the public sector. They are ready to collaborate and compete in a healthy manner in Hinduism and in accordance with the demands of globalization. They are ready to adapt and develop themselves to seize the opportunities of globalization without having to leave Balinese Hindu culture, ready to be a single parent. They can no longer claim to be a follower of the Hindu religion.

7) An example of the importance of reliability, skill, professionalism, and expertise in a professional field in carrying out domestic and public roles such as Dewi Kunti and Dewi Anjani, who is not only an educator of her sons in the domestic sector, but she is also a reliable and needed figure by the public. Thus, Srikandi is known as a figure who is able to maintain ethics in the domestic sector and is reliable in the public sector because of his skills. Based on the opportunities for emancipation and freedom in globalization, post-colonial Balinese Hindu women should be able to advance. Being more advanced does not mean that Balinese Hindu women have to survive in a metropolitan city, be able to immediately become socialites, or even become members of Jet $\mathrm{Z}$ to be more empowered. Being more advanced here can mean that more women are able and willing to compete in a healthy manner, collaborate internationally, become great and strong figures such as Dewi Kunti, Dewi Anjani, or Srikandi, are able to have a career outside the home and choose a profession according to their interests, 
talents, and competencies. Without having to leave her domestic role as a facilitator in educating her children and her role as her husband's companion at home.

\section{CONCLUSION}

Based on the description above, it can be concluded that the struggle for women's emancipation in achieving equality with men is reflected in Dewi Anjani, Srikandi, and Dewi Kunti. Dewi Anjani is a precolonial Hindu female figure in the art of wayang performance based on the Ramayana epic who is known as a woman with an egalitarian mentality, feeling that she has equal rights with her two brothers. Srikandi and Dewi Kunti are precolonial Hindu female figures in the Mahabharata epic-based wayang performing arts. Srikandi is a patriotic figure, able to be masculine and assertive like men, has a spirit of nationalism, and is courageous in a frontal and open way on the battlefield against the Pandavas' enemies. Meanwhile, Dewi Kunti is a responsible, wise, and tough mother figure as an educator and caregiver for the Pandavas, as well as a wife figure who is loyal to her husband, Pandu Dewanata.

The characters of the three pre-colonial Hindu women in the epic-based wayang art are very relevant as role models to reconstruct the post-colonial Balinese Hindu women's role in the midst of public problems and challenges of globalization in terms of : (1) demands for ethical and moral attitudes and behavior, (2) the demand for skills in using technology; (3) the need for gender equality; (4) the need for collaboration and healthy competition; (5) tough mental demands facing life's challenges; and (6) the need for reliability in carrying out domestic and public roles.

\section{ACKNOWLEDGEMENTS}

Special thanks are given to the research contributors so that the results of this research can be completed in the form of articles.

\section{REFERENCES}

[1] Simon, De, The Second Sex, Kehidupan Perempuan, Yogyakarta, Narasi, 2016.

[2] Karmini, Ni Wayan, Keterpinggiran Perempuan Hindu Pekerja Hotel Berbintang Lima Di Kawasan Sanur, Denpasar Selatan, Kota Denpasar (Disertasi), Denpasar, Universitas Udayana, 2011.

[3] Murni, Yustine Indah, Gerakan Sosial Pekerja Hotel Di Kabupaten Badung Perspektif Kajian Budaya (Disertasi), Denpasar, Universitas Udayana, 2011.

[4] Honour, TF dan Mainwaring, Sosiologi dan Bisnis, Jakarta, Bina Aksara, 1988.

[5] Pradana, Gede Yoga Kharisma, "Inovation in Cenk Blonk Performance : A Strategy of Empowering Local Language Through Balinese Shadow Puppet," in The 1st International Conference On Local Language, 2008. UNUD 2008. 1st ICLL, 2008, pp. 173-182.

[6] Pradana, Gede Yoga Kharisma, "Aplikasi Filosofi Tri Hita Karana Dalam Pemberdayaan Masyarakat Tonja di Denpasar," Jurnal Abdi Masyarakat, vol.1(2), pp. 61-71, 2021. DOI : https://doi.org/10.22334/jam.v1i2.10.

[7] Swandi, I Wayan, Arya Pageh Wibawa, Gede Yoga Kharisma Pradana, I Nyoman Suarka, "The Digital Comic Tantri Kamandaka : A Discovery For National Character Education," International Journal of Innovation, Creativity and Change, vol. 13(3), pp. 718-732, 2020.

[8] Gaib, H. et al.., Profil Perempuan Indonesia 2017, Jakarta, KP3A, 2017.

[9] Putra, I Nyoman Darma, Wanita Bali Tempo Doeloe Perspektif Masa Kini, Gianyar, Yayasan Bali Jani, 2003.

[10] Isnaniah, Siti, "Dewa Ruci: Sebuah Alternatif Sistem Pendidikan,” LiNGUA: Jurnal Ilmu Bahasa dan Sastra, vol.5(1), pp. 41-50. https://doi.org/10.18860/ling.v5i1.612.

[11] Ruastiti, Ni Made, I Komang Sudirga, I Gede Yudarta, "Cultural Enculturation Strategies For Bali Millennial Generations in The Digital Age," Multicultural Education, vol. 7(6), pp. 288-296, 2021.

[12] Ruastiti, Ni Made, I Komang Sudirga, I Gede Yudarta, "Model Innovative Wayang Wong for Millennial Generation to Meet 4.0 Industrial Revolution Era in Bali," Journal of Environmental Treatment Techniques, vol. 8(3), pp. 999-1004, 2020.

[13] Ruastiti, Ni Made, I Komang Sudirga, I Gede Yudarta, "Catur Guru Dalam Seni Pertunjukan Wayang Wong Millennial," Mudra Jurnal Seni Budaya, vol. 36(3), pp. 334-341, 2021.

[14] Pradana, Gede Yoga Kharisma, "Diskursus Fenomena Hamil di Luar Nikah Dalam Pertunjukan Wayang Joblar," Electronic Journal of Cultural Studies, vol. 1, pp. 11-27, 2012.

[15] Pradana, Gede Yoga Kharisma, "Implications of Commodified Parwa Shadow Puppet Performance For Tourism in Ubud, Bali," Journal of Business on Hospitality and Tourism, vol. 4(1), pp. 70-79, 2018. DOI : http://dx.doi.org/10.22334/jbhost.v4i1.103.g111. 
International Journal of Social Science (IJSS)

Vol. Issue.5 February 2022, pp: 643-656

ISSN: 2798-3463 (Printed) | 2798-4079 (Online)

DOI: https://doi.org/10.53625/ijss.v1i5.1307

[16] Pradana, Gede Yoga Kharisma., "Deconstruction Powers of Relation Behind The Shadow Puppet Performance For Tourism in Ubud Village, Bali," in The International Seminar of Building Collaboration and Networking in The Globalized World. UNUD 2017. 1st ISBCNGW, 2017, pp. 115-124.

[17] Rahmat, Kartika Sari Dewi, A. Andayani, Nugraheni Eko Wardhani, "Citra Emansipasi Perempuan Dalam Kisah Mahabarata: Pelurusan Makna Peran Dan Kebebasan Bagi Perempuan Modern,” ; Jurnal Masyarakat \& Budaya, vol. 19(2), pp. 203-217, 2017.

[18] Sunasri, I Gusti Ayu, Konflik Peran Perempuan Bali Di Desa Pemecutan Kaja, Kecamatan Denpasar Barat, Kota Denpasar (Tesis), Denpasar, Universitas Udayana, 2004.

[19] Pradana, Gede Yoga Kharisma, Sosiologi Pariwisata, Denpasar, STPBI Press, 2019.

[20] Suarmini, Ni Wayan, et al., "Peluang Dan Tantangan Peran Perempuan Di Era Revolusi Industri 4.0" in Strategi Pembangunan Nasional Menghadapi Revolusi Industri 4.0, 2018. Institut Teknologi Sepuluh Nopember 2018. SEMATEKSOS 3, 2018, pp. 128-131.

[21] Kumar, Ranjit, Research Methodology : A Step-By-Step Guide For Beginners, London, Thousand Oak, 2019.

[22] Barthes, Roland, Membedah Mitos-Mitos Budaya Massa, Jakarta, Jalasutra, 2007.

[23] Wahyudi, Aris, Lakon Dewa Ruci: Cara Menjadi Jawa, Yogyakarta, Bagaskara, 2012.

[24] Sudibyoprono, R. Rio, Ensiklopedi Wayang Purwa, Jakarta, Balai Pustaka, 1991.

[25] Tondowidjojo, John, Enneagram Dalam Wayang Purwa, Jakarta, Gramedia Pustaka Utama, 2013.

[26] Randya, M., "Telaah Karakterologi dan etika Tokoh Bisma dalam Pewayangan Jawa,". Harmonia Jurnal Pengetahuan dan Pemikiran Seni, vol.7(1), pp. 69-79, 2006.

[27] Heru, S Sudjarwo et al., Rupa dan Karakter Wayang Purwa, Jakarta, Kakilangit Kencana, 2010.

[28] Dharmika, Ida Bagus, Gede Yoga Kharisma Pradana, Ni Made Ruastiti,"Forest Conservation with The Basis of Customary Village and Religion Rules in Bali," International Journal of Advanced Science and Technology, vol.29(8), pp. 571-579, 2020.

[29] Pradana, Gede Yoga Kharisma, Komang Shanty Muni Parwati, "Local-Wisdom-Based Spa Tourism in Ubud Village of Bali, Indonesia," Russian Journal of Agricultural and Socio-Economic Sciences, vol. 8(68), pp. 188196, 2017.

[30] Atmaja, Gede Marhaendra Wija, Ida Ayu Komang Arniati, Gede Yoga Kharisma Pradana, "Implications of Enacment of Law Number 6 of 2014 on The Position of Villages in Bali, Indonesia," Asia Life Sciences, vol. 28(2), pp. 295-310, 2019.

[31] Rai S., I Wayan, I Made Indra Sadguna, I Gde Agus Jaya Sadguna, Gede Yoga Kharisma Pradana,'Tifa From The Land of Papua : Text and Context," Asia Life Sciences, vol. 28(2), pp. 335-354, 2019.

[32] Ruastiti, Ni Made Ruastiti and Gede Yoga Kharisma Pradana, "The Ideology Behind Sesandaran Dance Show in Bali," Journal of Sociology and Social Anthropology, vol. 11(2), pp. 78-85, 2020.

[33] Pradana, Gede Yoga Kharisma., "Corona in Pupuh Ginada Dasar : A Cultural Response to Crisis Situations Due To Corona Virus Pandemic". in The 5th International Conference on Climate Change : Climate Actions Toward Sustainable Development Goals (MDGs), 2021. Surakarta 2021. IOP Conference Series : Earth and Environmental Science Vol. 724(1), 2021, pp. 1-12.

[34] Dharmika, Ida Bagus and Gede Yoga Kharisma Pradana, "The Meaning of Rebo Buntung For Pringgabaya Villager, East Lombok During The Covid-19 Pandemic," Qualitative Report, vol. 26(9), pp. 2911-2923, 2021. DOI : https://doi.org/10.46743/2160-3715/2021.4769

[35] Atmaja, Gede Marhaendra Wija, Ida Ayu Komang Arniati, Gede Yoga Kharisma Pradana,"Bhineka Tunggal Ika as a Source Politics \& Identity of Indonesian Culture in The Formation of Law," Cultura. International Journal of Philosophy of Culture \& Axiology, vol. 17(2), pp. 57-72, 2020.

[36] Ruastiti, Ni Made, Anak Agung Indrawan, I Ketut Sariada,"Bentuk dan Makna Tari Renteng di Desa Saren, Nusa Penida, Klungkung, Bali,” Jurnal Kajian Bali, vol. 11(1), pp. 165-180, 2021.

[37] Ruastiti, Ni Made, Ni Wayan Karmini, I Made Sidia, "The Balinese Traditional Performance as a Media to Establish Identity and Strengthen Children Talents in The Middle of Global Disruption," Review of International Geographical Education, vol. 11(7), pp. 2513-2526, 2021.

[38] Geertz, H., The Javanese Family : A Study of Kinship and Socialization, USA, MPublishing, 1989.

[39] Giddens, A., The Constitution of Society : Teori Strukturasi untuk Analisis Sosial, Pasuruan, Pedati, 2003.

[40] Jazdi, N.,"Cyber Phsycal Systems in the Context of Industry 4.0," IEEE Computer Society, vol. 14, pp. 1-3. 2014. DOI : 10.1109/AQTR.2014.6857843.

[41] BKSTI, 2017, BKSTI ub.ac.id /wp-content/upload/2017/10/keynote Speker Drajad Irianto.pdf. 
[42] Ruastiti, Ni Made, Gede Yoga Kharisma Pradana, I Ketut Purnaya, Komang Shanty Muni Parwati, "The Royal Dinner Party Puri Anyar Kerambitan Tabanan: A Sustainable Cultural Tourism Attraction Based on Local Community" in The International Conference on Social Science, 2018. Nusa Dua 2018. The 1st ICSS, 2018, pp. 1448-1459. https://doi.org/10.2991/icss-18.2018.305.

[43] Hagerdal, Hans, Hindu Rulers, Muslim Subjects : Bali and Lombok in the Seventeenth and Eighteenth Centuries, Thailand, White Lotus Press, 2001.

[44] Dharmika, Ida Bagus, Gede Yoga Kharisma Pradana,"The Meaning of The Sutri Dance in Dewa Yadnya in a Digital Era to The People of Pakraman Lebih Village, Gianyar Bali," International Journal of Innovation, Creativity and Change, vol. 14(5), pp. 647-665, 2020.

[45] Arniati, Ida Ayu Komang, Gede Marhaendra Wija Atmaja, Gede Yoga Kharisma Pradana,"Moral and Religious Values in The Geguritan Dharma Prawerti Song in Bali," International Journal of Innovation, Creativity and Change, vol. 12(1), pp. 432-446, 2020.

[46] Nor Ichwan, Mohammad, Prof M. Quraish Shihab Membincang Persoalan Gender, Semarang, RaSAIL Media Group, 2013.

[47] Djarkasi, Agnes, Woman in Publik Sector, Peranan Perempuan dalam Kesetaraan Gender, Suatu Tinjauan Historis di Sulawesi Utara, Yogyakarta, Tiara Wacana, 2008.

[48] Lan, Thung Ju, "Perempuan dan Modernisasi," Jurnal Masyarakat dan Budaya, vol. 17(1), pp. 17-28, 2015.

[49] Kurniawan, Haris, Tendensi Sentral Pengarusutamaan Gender, Surabaya, Jembatan Ilmu, 2010.

[50] Kartono, Kartini, Psikologi Wanita, Mengenal Wanita Sebagai Ibu dan Nenek, Bandung, Mandar Maju, 2007.

[51] Purwadi, Mengenal Gambar Tokoh Wayang Purwa dan Keterangannya,Sukoharjo, Cendrawasih, 2013.

[52] Wibowo, D. E., "Peran Ganda Perempuan dan Kesetaraan Gender," Gender, vol. 3(1), pp. 356-364, 2011.

[53] Pradana, Gede Yoga Kharisma, I Nyoman Suarka, Anak Agung Bagus Wirawan, I Nyoman Dhana., "Religious Ideology of The Tradition of The Makotek in The Era of Globalization," Electronic Journal of Cultural Studies, vol. 9(1), pp. 6-10, 2016.

[54] Pradana, Gede Yoga Kharisma, Komang Trisna Pratiwi Arcana, "Hasil Pengelolaan Homestay Bercorak Budaya Tradisional Bali Ditengah Pengaruh Perkembangan Trend Millennial di Sektor Pariwisata," Jurnal Ilmiah Hospitality Management, vol. 11(1), pp. 1-12. 2020.

[55] Ruggiero, Adriane, Reconstruction. New York, Marshall Cavendish Benchmark, 2007. 